Volume 6

Number 3 Survey on Oil \& Gas

Article 11

$12-1-2020$

\title{
North Dakota--Dealing with Dubious Contracts for Conveying Land Statute of Limitations or Reformation for Mutual Mistake?
}

William P. Pearce

WPearce@fredlaw.com

Follow this and additional works at: https://scholarship.law.tamu.edu/journal-of-property-law

Part of the Property Law and Real Estate Commons

\section{Recommended Citation}

William P. Pearce, North Dakota--Dealing with Dubious Contracts for Conveying Land Statute of Limitations or Reformation for Mutual Mistake?, 6 Tex. A\&M J. Prop. L 93 (2020).

This Student Article is brought to you for free and open access by Texas A\&M Law Scholarship. It has been accepted for inclusion in Texas A\&M Journal of Property Law by an authorized editor of Texas A\&M Law Scholarship. For more information, please contact aretteen@law.tamu.edu. 


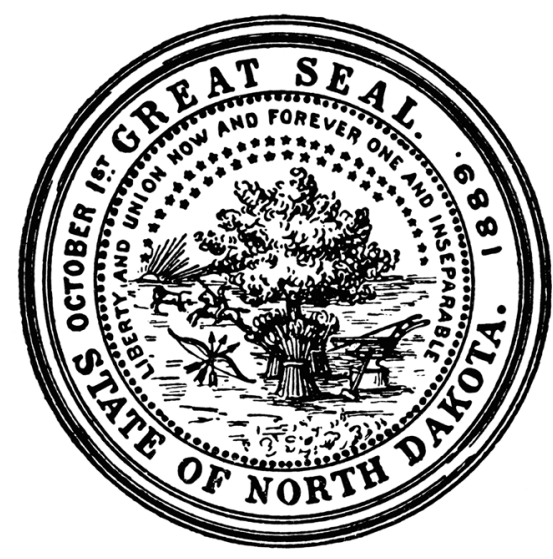

NORTH DAKOTA

DEALING WITH DUbious CONTRACTS FOR CONVEYING LAND

STATUTE OF LIMITATIONS OR REFORMATION FOR MUTUAL

MisTAKE?

\section{William P. Pearce}

The topic of this Article arose from a recent opinion by the North Dakota Supreme Court: Western Energy Corporation v. Stauffer. ${ }^{1}$ The case dealt with how the law handles changes in ownership of property, specifically land including underlying mineral interests, that come into dispute after substantial periods of time have passed, resulting in a need for the parties involved in the dispute to turn to the courts for a solution. The passing of a substantial amount of time often becomes the issue in resolving the dispute in these types of situations.

The opening paragraph in the Court's opinion in Western Energy states that "Western Energy appealed from a district court judgment finding its quiet title action pertaining to claimed mineral

DOI: https://doi.org/10.37419/JPL.V6.I3.11

1. 921 N.W.2d 431 (N.D. 2019). 
interests to be barred by applicable statutes of limitation and laches." Statutes of limitation are fairly straightforward and are discussed below as they are the determinative factor in the case. However, the specific goal here is to examine several of the approaches that can be taken in this kind of situation and how the issue is ultimately resolved. Raising the claim of "laches" is a rather vague concept, but it appears in some of these cases and has an interesting background, as discussed in the last part of this Article. The background of the case in question will be laid out first followed by the discussion of several traditional methodologies for resolving cases of this kind, generally, in the context of other court cases.

\section{WESTERn ENERGy CORPORATION V. STAUfFER}

On May 25, 1959, members of the Eckman family, owners of a tract of land, agreed to convey a portion of their real property to members of the Stauffer family using a typical contract for deed to accomplish the transfer. The contract for deed contained a reservation of the underground oil, gas, and other minerals in the property in question, which is not an unusual practice in the western part of North Dakota where there are large underground deposits of these minerals. The contract for deed was on a five-year payment plan, after which the Eckmans were to convey the tract to the Stauffers by a warranty deed, the usual document used for completing the transfer of land. The actual conveyance of the property by the warranty deed was made very early, in June 1959, rather than on a five-year plan, but the timing is not particularly relevant to the case. However, the source of the ensuing problem was that the June 1959 warranty deed did not contain any reservations of minerals, although it expressly stated that the deed was given "in fulfillment of the contract for deed issued on the 25th of May 1959."2

At this point, a potential problem came into existence because there was an uncertainty regarding the status of the mineral interest. The apparent agreement between the Eckmans and the Stauffers was that $50 \%$ of the minerals were to be reserved, meaning they would not be included in the grant of the land made by the warranty deed. The statement that the warranty deed from the Eckmans to the Stauffers

2. Id. at 433 . 
was made in fulfillment of the contract for deed appears to support the passing of the mineral interests as well as the surface of the land, since there was no actual reservation of minerals in the deed itself. Under North Dakota statutory law, a conveyance of mineral rights in real property grants all minerals except those specifically excluded by name:

\begin{abstract}
All conveyances of mineral rights or royalties in real property in this state, excluding leases, shall be construed to grant or convey to the grantee thereof all minerals of any nature whatsoever except those minerals specifically excluded by name in the deed, grant, or conveyance, and their compounds and byproducts. $^{3}$
\end{abstract}

Since the warranty deed did not contain any mineral reservation, or apparently any reference to mineral interests, it appears to have conveyed all of the mineral interests in the tract in question to the Stauffers. A conveyance of land that does not explicitly include a reservation of minerals automatically includes the minerals that are a part of the land unless there has been an intentional severance of minerals from the land. Since the Eckmans did not include any such reservation or severance of minerals in their warranty deed to the Stauffers, the land with the minerals passed to the Stauffers. This result has been clearly stated by the North Dakota Supreme Court, following the established rule that a grant without a reservation shall be interpreted in favor of the grantee, and "[a] conveyance of land, without any exception or reservation of minerals constitutes a conveyance of 100 percent of the minerals as well as the surface. ${ }^{4}$

A quiet title action was filed by Western Energy Corporation in 2016 against a number of successors of the Stauffers. The Court's opinion does not does not specify the detailed basis for the quiet title action, but apparently numerous conveyances, oil and gas leases, and similar transactions were carried out by both the Eckmans and the Stauffers and their successors between 1959 and 2016. Beginning in 1978, the Eckmans apparently began entering into agreements

3. N.D. CENT. CODE $§ 47-10-24$ (2014).

4. Acoma Oil Corp. v Wilson, 471 N.W.2d 476, 482 (N.D. 1991) (citing Sibert v. Kubas, 357 N.W.2d 495, 496 (N.D. 1984)). 
conveying mineral interests, which they may have believed they had retained and were entitled to when the warranty deed was delivered to the Stauffers. Western Energy Corporation entered the picture in 1989 and 1990 by acquiring mineral interests, including mineral interests that were all or portions of the interests the Eckmans had failed to reserve in the June 1969 warranty deed. The Court does not specify the various mineral interests in detail. However, the disputed mineral interests must be the basis for the quiet title action, since the only mineral interests that Western Energy would be seeking to obtain by quiet title action against the Stauffer successors would be the mineral interests that passed to the Stauffers via the original warranty deed that contained no mineral reservation.

The Supreme Court opinion does not specify from whom these interests were derived, but presumably it would have been from some or all of the persons involved in the case in an effort to clarify the actual ownership of the mineral interests in the land in question. Although the action was nominally brought as a quiet title action, ${ }^{5}$ the Supreme Court points out that the relief requested was not for quiet title. Instead, it was actually for reformation of the warranty deed, presumably because the deed did not contain a reservation of minerals and was different from the original agreement. ${ }^{6}$ To successfully establish a basis for a reformation of the deed would require that there had been a sufficient mistake or mistakes to subsequently alter the terms of the deed. The district court concluded that the discrepancy between the contract for deed and the warranty deed itself was not sufficient to establish mutual mistake that could support a reformation.

After several years, the situation had become more complicated, so a simple reformation by inserting a missing mineral reservation into the deed had become difficult, in view of all of the various transactions. The Supreme Court, on appeal from the district court, pointed out that numerous conveyances, oil and gas leases, and similar transactions were completed by both the Eckmans and Stauffers, as well as their successors in interest, during the period of time between the execution of the 1959 deed and the filing of the quiet title action in 2016. As stated above, the Eckmans conveyed mineral interests to others, perhaps even interests that they may have deemed

5. See Actions to Quiet Title and Determine Claims to Real Estate, N.D. CENT. CODE. $\$ 32-17-1$ et seq. (2010).

6. W. Energy Corp., 921 N.W.2d at 434. 
they owned, based on the agreement for a mineral reservation in the contract for deed to the Stauffers.

In reality, the warranty deed should accomplish exactly what it says it intends to do. If there is no reservation of minerals stated in the deed, would that not mean that it was certain that no mineral reservation was intended? Despite the action being framed as a quiet title action, as noted above, the North Dakota Supreme Court recognized that the relief requested by Western Energy was actually to reform the warranty deed to comply with the original contract, which contained the reservation of minerals. ${ }^{7}$ So, the issue that forms the core of the case is: Does the law allow for changes, or corrections, to be made in 2016 in a warranty deed that was created and delivered in 1959? Not surprisingly, the answer in the Western Energy case was "no". The point of this Article is to look at a few of the more common legal methods that may be used to attempt to seek a "yes" answer in a case of this kind.

\section{REFORMATION OF A DEED or CONTRACT FOR Mutual Mistake}

The Western Energy quiet title action set the stage for establishing exactly who owns certain underlying mineral interests, presumably including those originally owned by the Eckmans, when there was no reservation in the warranty deed. This is the basic issue brought forth in a quiet title action, which is "a proceeding to establish the plaintiff's title to land by bringing into court an adverse claimant and there compelling him either to establish his claim or be forever after estopped from asserting it." 8 Although the proceeding was brought as a quiet title action, the Court shows that the relief sought was actually to proceed with a reformation of the warranty deed. The theory behind reformation of a document is that in the course of creating it the parties inadvertently made a "mutual mistake." If it can be proven that there was a mutual mistake, then there is a basis for a court to approve the document to be revised to correct the mistake. In other words, the court can order the reformation or correction of the original document to adapt it to the document that presumably was

7. See also Larry A. DiMatteo, Equity's Modification of Contract: An Analysis of the Twentieth Century's Equitable Reformation of Contract Law, 33 NEW ENG. L. REV. 265 (1998) (reformation of contracts).

8. Quiet, BLACK's LAW DiCTIONARY 1416 (4th ed. 1968). 
intended to be created by the individuals who wrote it. Reformation of a written document is an appropriate result when the surrounding circumstances justify it. A court will grant relief by way of reformation of a written instrument resulting from a mutual mistake, but all of the circumstances must be taken into consideration:

Each case involving the reformation of a contract on grounds of fraud or mutual mistake must be determined upon its own particular facts and circumstances. In considering whether or not a mutual mistake exists, the court can properly look into the surrounding circumstances and take into consideration all facts which disclose the intention of the parties. ${ }^{9}$

If the facts and circumstances are sufficiently clear to justify the granting of a reformation of the document or documents in question, of course, the court would look favorably upon granting it, assuming that the case is not more appropriately handled by a statute of limitations, as in the Western Energy case. ${ }^{10}$

The North Dakota statutory basis for approving reformation of a document is set out as follows:

When, through fraud or mutual mistake of the parties, or a mistake of one party which the other at the time knew or suspected, a written contract does not truly express the intention of the parties, it may be revised on the application of a party aggrieved so as to express that intention so far as it can be done without prejudice to rights acquired by third persons in good faith and for value. ${ }^{11}$

The lower court was not convinced that the discrepancy between the warranty deed and the contract for deed - the reservation of the mineral interests - was sufficient to establish mutual mistake. Not surprisingly, the Supreme Court's conclusion was the same simply

9. Ell v. Ell, 295 N.W.2d 143, 150 (N.D. 1980).

10. See Zabolotny v. Fedorenko, 315 N.W.2d 668 (N.D. 1982) (holding that reformation was the most logical and appropriate resolution).

11. N.D. CENT. CODE § 32-04-17 (2010). 
because it would seem to have been peculiar and unlikely that the parties would have not have noticed in examining the recorded documents that there was a mineral reservation in the original contract for deed but nothing of that kind contained in the warranty deed. In fact, it seems relatively straightforward that the Stauffers ought to have acquired the mineral interest since they received a warranty deed that did not contain any mineral reservation and accordingly would necessarily have transferred all of the mineral interests.

In addition to mutual mistake, it is possible in some cases for fraud of some kind to have occurred, but there appears to be no evidence of fraud having been a factor in the Western Energy case. However, there could always be something that occurs other than the sheer overlooking of some step in the process or transferring an interest in land, and the person bringing the claim has the burden to explain the problem. As the North Dakota Supreme Court has pointed out:

A party seeking reformation has the burden to prove by clear and convincing evidence that a written agreement does not fully or truly state the agreement the parties intended to make. ${ }^{12}$ The burden of proof rests on the party who seeks a reformation to prove that the written instrument does not fully or truly state the agreement that the parties intended to make. ${ }^{13}$

Any case involving a claim for reformation of a document or documents must take into account all of the relevant facts in any given situation, meaning there is no standard scenario that will support a reformation. Included in the concept of "relevant facts" in modern times would be the possibility of introducing parol evidence, meaning oral evidence rather than written evidence, in support of a claim for reformation, but the standard for this is generally high:

The Supreme Court's sanctioning of the use of circumstantial parol evidence to prove mutual mistake

12. Dixon v. Dixon, 898 N.W.2d 706, 711 (N.D. 2017) (quoting Freidig v. Weed, 868 N.W.2d 546, 549 (N.D. 2015)).

13. Ell, 295 N.W.2d at 150 (citing Oliver-Mercer Electric Cooperative, Inc. v. Fisher, 146 N.W.2d 346, 356 (N.D. 1966)). 
is noteworthy here. Initially the Court acknowledged a high standard for use of parol evidence to prove mutual mistake: such evidence must be clear, satisfactory, specific, and convincing, and a court of equity will not grant reformation upon a mere preponderance of evidence, but only upon certainty of error. ${ }^{14}$

Whether a mistake exists in a document that would have been sufficient to justify a claim of reformation involves looking at "each case involving the reformation of a contract on grounds of fraud or mutual mistake must be determined upon its own particular facts and circumstances." 15

It should also be kept in mind when faced with a claim for reformation that it is not always a simple matter to determine whether there is a clear mistake in a contract:

The inconsistency of the decisions as to the effect of mistake in contracting is due to the fact that AngloAmerican law is torn between the desire for stability of commercial transactions and the feeling that is it unfair to hold a party to a contract that he made without complete information about all the relevant circumstances. The latter consideration rests on a sense of fair play which looks with disfavor on permitting anyone to reap an advantage from another party's mistakes. ${ }^{16}$

Therefore, the essential basis for a successful action for reformation of a document is that it must be shown by substantial evidence that an actual mistake occurred in the creation of the document that is significant enough that the mutual intention of the parties to the document is not what was included in the document. As the Court stated in the Western Energy case:

14. Alexandra P. Everhart Sickler, Recent Developments in North Dakota Contract Law, 92 N.D. L. REV. 19, 37 (2016).

15. Mau v. Schwan, 460 N.W.2d 131, 134 (N.D. 1990).

16. Ralph A. Newman, Relieffor Mistake in Contracting, 54 CORNELL L. REV. 232, 236-37 (1969). 
Further, the district court concluded the discrepancy between the contract for deed and the warranty deed is not enough to establish mutual mistake. Because it found that Western had not met the burden of proof to establish mutual mistake at the time of conveyance, the district court entered judgment quieting title of the minerals to the Stauffers. ${ }^{17}$

To establish the existence of a mistake that would be sufficiently important to justify a reformation of a document, the party claiming the existence of a genuine mistake must prove there was a firm basis for alleging the claim:

Here, the district court found numerous transactions involving the property and mineral rights occurred in the decades since the warranty deed was executed and recorded. The district court found these transactions, including a completed title opinion, gave all parties reason to review the title record. An examination of the title record would have disclosed the difference between the contract for deed and the warranty deed. The district court thus concluded that any alleged mutual mistake was, or should have been, discovered with reasonable diligence in 1959 when the documents were executed, or in the intervening fifty-nine years since the execution of the warranty deed....A simple examination of the title records would have revealed competing leases on the property as well as the discrepancy between the 1959 contract for deed and the warranty deed. ${ }^{18}$

In Anderson v. Selby, ${ }^{19}$ the North Dakota Supreme Court also held that there was no basis for a reformation action in a somewhat similar situation to the one in Western Energy. The Andersons had conveyed a parcel of land, reserving oil, gas, and other minerals, and

17. W. Energy Corp. v. Stauffer, 921 N.W.2d 431 (N.D. 2019).

18. Id. at 435 .

19. 700 N.W.2d 696 (N.D. 2005). 
they also intended to reserve a flowage easement. This easement was a right to raise the elevation of the water table in connection with a dam project in which the Andersons had offered the easement to the United States Army Corp of Engineers in charge of the project. However, the warranty deed from the Andersons to Selby did not contain a flowage easement. The Andersons, not wishing to lose the large payment they would have received from the Corps for the easement, sued Selby, seeking a reformation of the deed to include a reservation of the easement, which had not been included in the deed. Selby denied that there had been a mutual mistake regarding a reservation of the easement. The district court granted summary judgment in favor of Selby on the Andersons' claim, thereby declining to grant a reformation. On appeal by the Andersons, the North Dakota Supreme Court determined that there was sufficient evidence to consider the matter:

Although the Andersons have the ultimate burden of proof to show by clear and convincing evidence that they are entitled to reformation because of a mistake which Selby at the time knew or suspected, we believe there is evidence in this record which supports an inference that such a mistake was made. We therefore conclude summary judgment was not appropriate on the Andersons' claim for reformation. ${ }^{20}$

In other words, it was a matter of the two different courts viewing the evidence differently as to whether there could have been a mutual mistake that could have supported a reformation of the deed.

\section{WeHNER v. SCHROEDER: SOME SimiLARITIES TO WESTERN ENERGY BUT A DIFFERENT RESULT}

Another case, Wehner v. Schroeder, ${ }^{21}$ which was similar but different to the Western Energy case, came before the North Dakota Supreme Court in 1984. The plaintiff sought reformation of a warranty

20. Id. at 701 .

21. 354 N.W.2d 674 (N.D. 1984). The earlier Wehner v. Schroeder case, 335 N.W.2d 563 (N.D. 1983), ended in a remand which then led to the subsequent 1984 case. 
deed on the same grounds as in Western Energy - that a mineral reservation agreed upon in a contract for deed had been omitted from the subsequently recorded warranty deed. However, there was a peculiar quirk because the 1950 contract for deed stated that the "second parties," the Schroeders, who were the grantees in the deed, "retain $50 \%$ of all oil, gas and minerals on said land." The peculiarity is that the grantees were not the ones who were to retain the mineral interest since that was owned by the grantors [the Wehners], who would necessarily be the only persons who could be able to retain any of the minerals since they owned them. Both the contract for deed and the warranty deed had been recorded in 1950. Since that was done, the tract became the property of the Schroeders, but the $50 \%$ mineral interest was left somewhere in limbo because a contract for deed is not a grant and does not actually convey an interest in land but simply is a contractual promise to convey it via a warranty deed.

In 1981, the Wehners brought an action to reform their warranty deed, stating that "second parties" was an error, and they intended to have "first parties," meaning themselves as the grantors in the deed. They also asserted that the mineral reservation in the contract for deed was omitted from the warranty deed due to an "innocent mutual mistake" made by both of them and the Schroeders. Other parties had acquired some interests, but it is not necessary to look into that aspect. The district court found that a mutual mistake has been made between the Wehners and the Schroeders regarding the omission of the mineral reservation in the warranty deed, and this provided the basis for approving a reformation of the document. The question of reformation of a contract or other kind of document is often referred to as a matter for the "equity" courts, as mentioned later in this article: "A court of equity will grant relief by way of reformation of a written instrument, resulting from mutual mistake where justice and good conscience so dictate." 22 In affirming the grant of reformation from the district court in Wehner v. Schroeder, the North Dakota Supreme Court summarized as follows:

We believe that in order to bar reformation under these particular circumstances, the fault of the party

22. Zabolotny v. Fedorenko, 315 N.W.2d 668, 671 (N.D. 1982) (citing Cokins v. Frandsen, 141 N.W.2d. 796, 798 (N.D. 1966)). 
requesting relief must amount "to a failure to act in good faith and in accordance with reasonable standards of fair dealing." Restatement (Second) of Contracts $\S$ 157 (1981)....The trial court found no evidence that the Wehners failed to act in good faith or in accordance with reasonable standards of fair dealing. We have reviewed the record in this case and cannot say that the trial court erred in this regard.

...

The trial court found that a mutual mistake had occurred, and, as we stated earlier, that finding is not clearly erroneous. The doctrine of merger therefore does not bar reformation in this case. ${ }^{23}$

In the law of real property, the doctrine of merger stands for the proposition that a contract for the conveyance of real property merges into the related deed of conveyance:

One of the most firmly established common law doctrines governing real property involves the merger of rights stemming from a land sale contract into the deed that consummates the transaction.... In essence, because the deed is presumed to supersede all preceding negotiations and agreements, all rights and remedies of the parties in relation to the transaction must be determined by the deed. Most practitioners prepare real estate contracts with the belief that the doctrine will apply and merge the provisions of the contract in the deed. ${ }^{24}$

Therefore, any guarantees made in the contract that are not reflected in the deed are extinguished when the deed is conveyed to the buyer of the property. In other words, the Court seems to be saying that the approved reformation in this case essentially blends the contract and the warranty into a single entity, which was appropriate in view of the approval of the claim for reformation. A number of other cases seeking reformation of documents have been brought over the

23. Wehner, 354 N.W.2d at 679.

24. Barry M. Goldman, Common Law Doctrine of Merger: The Exceptions are the Rule, 13 U. BALT. L. REV. 19 (1983). 
years before the North Dakota Supreme Court, and there is one opinion, granted in 1966, which seems particularly lucid in dealing with this issue. In Cokins v. Frandsen, the issue arose when a buyer and a seller entered into an agreement for the purchase and sale of a real estate tract on which a restaurant was located. In the course of an engineering survey it was discovered that the description of the tract in the agreement was erroneous. The buyers brought an action for reformation to correct the instrument. At the outset, the Court stated clearly the basic situation required in order for reformation to take place:

In order that the court may order reformation of the description of real estate in an instrument, it must appear that there has been a mutual mistake. In other words, it must be shown that, at the time of the execution of the agreement to sell, both parties intended to say something different from what was said in the instrument. In such event, equity has the power to reform the instrument to correct the mutual mistake of the parties. ${ }^{25}$

The Court in Cokins, as opposed to some of the other cases, determined that a mutual mistake had been by both the buyer and the seller in drafting the purchase agreement, due to an error in the description of the tract of land in question. Accordingly, this was an appropriate case for the equitable relief of reformation:

There being a mutual mistake in the description, such mutual mistake justifies the reformation of the description in the purchase agreement, and the judgment of the trial court granting reformation of the description in the purchase agreement and the deed is affirmed. ${ }^{26}$

\section{Statute of Limitation: Closing the Gate}

25. Cokins v. Frandsen, 141 N.W.2d 796, 799 (N.D. 1966) (citing Williams v. Hebbard, 92 P.2d 657 (Cal. 1939)).

26. Id. at 800 (citing Wilson v. Pulsfut, 49 N.W.2d 102 (N.D. 1951)). 
As discussed above, the attempt to alter the contract and warranty deed problem in the Western Energy quiet title action by reformation based on mutual mistake failed due to a lack of any basis for asserting a "mutual mistake." The actual solution the district court used, and the North Dakota Supreme Court approved, was the Statute of Limitations. The extensive lapse of time during which there was no complaint from Western Energy Corporation simply shut the matter down insofar as seeking a reformation. As pointed out by the North Dakota Supreme Court at the opening of its opinion, Western Energy Corporation appealed from a district court judgment that found its quiet title action to have been barred by applicable statutes of limitation and laches, and the mineral interests at issue having been awarded to the Stauffers. Accordingly, the district court's judgment was affirmed.

The term "laches" used in the Court's statement is discussed below. At this point, it is the statute of limitations that is the determining factor. The North Dakota statute of limitations pertaining to conveyances such as occurred in this case is N.D. Cent. Code Ann. $\S 28-01-15$, labeled in the code volume as "Actions having ten-year limitations." There are several subsections to this statute, and the Court cites $\S 28-01-15(2)$, as the district court had also done, which provides that any legal action based on contracts or any other instruments affecting title to real property must be commenced within ten years following the time the claim for relief accrues. Accordingly, since a substantial number of years more than ten had passed from the delivery of the warranty deed in 1959 to the bringing of the quiet title action by Western Energy in 2016 - 57 years - there was clearly no question that the quiet title action must disappear, and the Stauffers finally became established as the owners of the mineral interest in question after what clearly appeared to be an extended period of uncertainty and confusion.

The history of Statutes of Limitation is an interesting one. Such principles developed first under English law and, as with many other legal principles, gradually expanded to become parts of American law:

The principle [statutes of limitation] was first adopted in English law in connection with actions for the recovery of real property....The various States [American] possess their own statutes of limitation 
which are modeled in the main upon the English but differ widely in their minor details. ${ }^{27}$

In fact, it has been pointed out that the concept of statutes of limitation may actually be traced as far back as to ancient Greece, and the first one to appear pertaining to real property actions under English law was a 1487 statute enacted during the reign of King Henry VII. The first such English statute was adopted by American colonies before the 1776 Revolution and ultimately became the foundation of nearly all subsequent American statutes of limitation. ${ }^{28}$

The statutes of limitation constitute a very useful factor in the American legal system and by no means are they intended to provide an easy way for courts to limit the number of cases that may be piling up on the dockets. They have a definite purpose, which is clearly reflected in the analysis and opinion of the Supreme Court in this case, as well as in the same result originally reached in the district court. The following summaries of the function and purpose of the statutes of limitation demonstrate the underpinning of the clearly appropriate result in this case:

Statutes of limitation are vital to the welfare of society, and are favored in the law. They are found and approved in all systems of enlightened jurisprudence. They promote repose by giving security and stability to human affairs; important public policy lies at their foundation. Thy stimulate ... activity and punish negligence. While time is constantly destroying evidence of rights, they supply its place by a presumption which renders proof unnecessary. Mere delay, extending to the limit prescribed, is itself a conclusive bar. ${ }^{29}$

A good characterization for statutes of limitation is they provide a kind of repose, preventing dubious claims from possibly lingering forever in the judicial system:

27. Statute of limitations, ENCYCLOPEDIA BRITANNICA (14th ed. 1953).

28. Tyler T. Ochoa and Andrew Wistrich, The Puzzling Purposes of Statutes of Limitation, 28 PAC. L.J. 453, 454 (1997).

29. Id. at 456 (quoting Wood v. Carpenter, 101 U.S. 135, 139 (1879)). 
The statute of limitations is a statute of repose, enacted as a matter of public policy to fix a limit within which an action must be brought, or the obligation is presumed to have been paid, and is intended to run against those who are neglectful of their rights, and who fail to use reasonable and proper diligence in the enforcement thereof....These statutes are declared to be 'among the most beneficial in our books' 'They rest upon sound policy, and tend to the peace and welfare of society.'.... The underlying purpose of statutes of limitation is to prevent the unexpected enforcement of stale claims concerning which persons interested have been thrown off their guard by want of prosecution. ${ }^{30}$

\section{LAches: An Old-Timer In Legal History BUt StiLl Alive}

The North Dakota Supreme Court's opinion in the Western Energy case discussed above opens with a reference to the district court judgment "finding its quiet title action to be barred by applicable statutes of limitation and laches." The actual holding was the action was effectively barred by the statute of limitation. The word "laches" is an old term that evolved from Latin ("laxus") and Old French ("laschesse"), meaning laxness, slackness, negligence, and the like, usually in the course of legal matters. Laches is embedded in the legal concept of "equity," which has been described in a variety of ways. A typical legal description of equity is:

In its broadest and most general signification, this term [equity] denotes the spirit and the habit of fairness, justness, and right dealing - the rule of doing to all others as we desire them to do to us; or; as it is expressed by Justinian, "to live honestly, to harm nobody, to render to every man his due."31

30. Id. (citing Pashley v. Pacific Elec. Co., 153 P.2d 325, 326 (Cal. 1944)).

31. Equity, BlaCK's LaW DiCTIONARY (Rev. 4th ed. 1968). (Justinian was, of course the Byzantine emperor from A.D. 527 to 565, who compiled the famous book of laws entitled the Justinian Code.). 
Having defined "equity," we can see how the concept of "laches" is embedded into the function of equity as an integral part of the legal process carried on by the courts:

Generally speaking, laches is a defense in equity that stands for the proposition that a court will not find for the plaintiff if the plaintiff delayed in bringing the case, and that delay harmed the defendant.... Accordingly, laches has traditionally had two, or at most three, components - delay, a position change for the worse, and a loss of evidence." 32

Unreasonable delay in bringing an action before a court is not the sole feature of laches but it establishes the fundamental basis of this concept insofar as it affects an opposing party:

Laches is a delay or lapse of time in commencing an action that works a disadvantage or prejudice to the adverse party because of a change in conditions during the delay. ${ }^{33}$

Laches does not arise from a delay or lapse of time alone, and in addition to the time element, the party against whom laches is sought to be invoked must be actually or presumptively aware of his rights and must fail to assert them against a party who in good faith permitted his position to become so changed that he could not be restored to his former state. ${ }^{34}$

In the historical legal context, laches came to be appropriated by the English chancery courts, where decisions could be made by the judges that were more flexible than what would be required under the strict legal rules that had been established under the common law. ${ }^{35}$

32. Kathryn E. Fort, The New Laches: Creating Title Where None Existed, 16 GEO. MASON L. REV. 357, 365 (2009).

33. Williams Cty. Soc. Servs. Bd. v. Falcon, 367 N.W.2d 170, 174 (N.D. 1985).

34. Burlington N., Inc. v. Hall, 322 N.W.2d 233, 242 (N.D. 1982).

35. Kermit L. Hall, The Magic MirRor: LaW in American History 22 (1989) ("Equity, however, had emerged in the colonies as a matter of practice, if not of form. Seventeenth century colonial lay judges exercised a kind of equity through 
The basic outcome of the application of laches is that a legal right or claim may not be enforced or allowed if an unreasonably long delay in asserting the right or claim has prejudiced the other party. Historically, there was a kind of connection between laches and statutes of limitation, possibly on the theory that the mere passage of enough delay in raising a claim of a mistake was sufficient for the court to render a negative ruling. However, they are not the same, and the court in the Western Energy case, while ruling on the basis of the statute of limitations, was also ruling that the discrepancy between the contract for deed and the warranty deed in that case was not enough to establish the existence of a mutual mistake.

Laches is a defense that can be invoked when the plaintiff has delayed in bringing a suit. But laches is not concerned merely with the fact of delay. It matters why the plaintiff delayed bringing the claim and what effect that delay had on the defendant. In doctrinal terms, the delay must be "unreasonable" and cause "prejudice." It is this focus on considerations other than the mere passage of time that strongly distinguishes laches from the statutes of limitations. ${ }^{36}$

Accordingly, there is a significant distinction between statutes of limitation and the doctrine of laches when applied to a case such as Western Energy, as reflected in the North Dakota Supreme Court's opinion in the case, and in the following statement:

"Laches, a term for slackness or negligence, used particularly in law to signify negligence on the part of a person in doing that which he is by law bound to do, in allowing an unreasonable time to elapse in asserting a right, seeking relief, or claiming a privilege. Statutes of limitation specify the time within which various

the laxity with which they followed common law precedents."). The chancellor, who was the judge presiding over the chancery court, was entitled to modify the application of strict legal rules and grant relief if that seemed appropriate in the particular circumstances.

36. Samuel L. Bray. A Little Bit of Laches Goes a Long Way: Notes on Petrella v. Metro-Goldwyn-Mayer, Inc., 67 VAND. L. REV. 2 (2014), citing 1 Dan B. Dobbs, LAW OF REMEDIES-EQUITY-RESTITUTION 103 (2d ed. 2013). 
classes of actions may be brought, and various statutes granting remedies, etc., impose a definite time within which legal action must be taken. ${ }^{37}$

The concept of "equity" is mentioned a number of times above, ${ }^{38}$ though it is not feasible to attempt to discuss it in depth here. In a legal context, it suggests a system that recognizes that the law can work, to a limited extent anyway, with a reasonable amount of flexibility without damaging its authority. This was very well said nearly 100 years ago, with regard to property, by the great American legal scholar Roscoe Pound:

More and more the tendency is to hold that what the law should secure is satisfaction of the owner's reasonable wants with respect to the property - that is those which consist with the like wants of his neighbors and the interests of society. ${ }^{39}$

37. ENCYCLOPEDIA BRITANNICA, supra note 27.

38. See, e.g., supra notes $14,22,25,31$ and 32 .

39. Roscoe Pound, The SPIRIt of THe COMMOn Law, 186 (1921). 